\author{
Andrzej Kowalczyk \\ Uniwersytet Warszawski \\ Wydzial Geografii i Studiów Regionalnych \\ 00-927 Warszawa, ul. Krakowskie Przedmieście 30 \\ tel. 048225521512 \\ akowalczyk@uw.edu.pl
}

\section{PODEJŚCIE POSTMODERNISTYCZNE W GEOGRAFII TURYZMU - NIEUCHRONNOŚĆ CZY/I MODA?}

\begin{abstract}
„....sens rzeczy będqcych przedmiotem naszego poznania zawsze zawiera $w$ sobie więcej niż może ogarnqć nasza świadomość, tak że nie można nigdy uzyskać o nich wiedzy absolutnie pewnej i niepowtarzalnej. " (ŚWIĘCICKA 1993, s. 49)
\end{abstract}

\section{THE POSTMODERNIST APPROACH IN THE GEOGRAPHY OF TOURISM - INEVITABLE AND/OR FASHION?}

Zarys treści: Widoczne w geografii wplywy podejścia postmodernistycznego można odnaleźć również w geografii turyzmu. Niejednoznaczność terminu „turystyka”, różnorodność motyWacji i zachowań turystów itp., jak również słabość metodologiczna geografii turyzmu (wynikająca w dużym stopniu z podanych wyżej przyczyn i z braku odpowiednich danych statystycznych) sprawiają, że przyjmowane przez zajmujących się nią badaczy podejście postmodernistyczne jest podyktowane nie tylko modą, ale jest również pewną koniecznością. $\frac{\text { Słowa kluczowe: postmodernizm, turystyka, geografia tury- }}{\mathrm{zmu} \text {. }}$

\section{WROWADZENIE}

Czy można uważać za turystę kilkuletnie dziecko, które, nie pytane przez rodziców o zdanie, wyjeżdża z nimi na wakacje na Majorkę? Czy jest wyjazdem turystycznym nasz wyjazd do nielubianej cioci (która mieszka w górach)? Jeżeli przyjąć, iż Zarówno wspomniane dziecko, jak i my jesteśmy turystami, to czy w podanych sytuacjach spelniony jest warunek dobrowolności wyjazdów turystycznych?

Jak należy traktować wycieczkę mieszkańca centrum Berlina nad leżące w granicach miasta jezioro Wansee? Czy mieszkaniec podparyskiego Les Ulis, który przyjeżdża w niedzielę do Paryża,
"... the sense of things subject to our cognition always contains more than our awareness is capable of perceiving. so it is not possible to have absolutely certain and unique knowledge about them." (SWIECICKA 1993, p. 49)

Abstract: Traces of the postmodernist approach in geography can also be found in tourism geography. The ambiguity of the term 'tourism', differing tourist behaviours and motivations etc., as well as the methodological weakness in tourism geography (largely resulting from this and from the lack of appropriate statistical data) lead researchers to take a postmodernist approach, not only because it is in fashion, but also because it is necessary.

Key words: postmodernism, tourism, geography of tourism.

\section{INTRODUCTION}

Can a small child, who goes with its parents on holiday to Mallorca, without being asked for an opinion, be considered a tourist? Is a visit to an aunt, who lives in the mountains and whom we do not like, a tourist trip? If we assume that both we and the child are tourists, then is the condition of free choice in travelling met in the above situations?

How should we treat a trip made by an inhabitant of central Berlin to the lakes at Wannsee within the city borders? Is an inhabitant of Les Ulis near Paris, who 
aby zobaczyć w jednym z muzeów nową wystawę jest turystą (należy nadmienić, że człowiek ten codziennie przyjeżdża do Paryża do pracy)? Jak w podanych sytuacjach rozumieć zapis $w$ definicjach turystyki, iż turyści w czasie swoich wyjazdów opuszczają miejsce stałego zamieszkania? Czy chodzi o wyjazd poza aglomeracje miejska, czy może tylko własną dzielnicę? Czy osoba, która od lat w ciągu tygodnia codziennie jeździ do innego miasta do pracy może przybyć w weekend do tego samego miasta jako turysta?

Czy jest turystą badacz, który kilka razy w roku wyjeżdża na naukowe spotkania (m.in. do Cancun i Las Vegas), albo biznesmen z Australii, który przyjechał do Nusa Dua, aby omówić z dyrekcją jednego z hoteli sprzedaż oprogramowania komputerowego? Przecież ich wyjazdy są związane z obowiązkami zawodowymi.

Czy jest turystą osoba mająca od lat kłopoty ze zdrowiem, która przyjechała w celach leczniczych do Bad Homburg? Przecież dbałość o zdrowie jest nie tylko wyborem człowieka, ale również czymś w rodzaju powinności związanej $\mathrm{z}$ biologiczną stroną naszego istnienia.

Czy można uznać za turystę człowieka, który przyjechal z Ukrainy do Polski i sprzedał w przygranicznym miasteczku kilka paczek papierosów? Czy jest wreszcie turystą podróżnik, którego życie wypełnia w dużej mierze zwiedzanie świata i który utrzymuje się ze sprzedaży zdjęć oraz tekstów do gazet, będących wynikiem jego podróży? W obu przypadkach turystyka (może „turystyka”?) jest źródlem dochodów.

Tego typu pytania można mnożyć. Pokazują one niedoskonałość potocznych definicji turystyki jako zjawiska spolecznego, ekonomicznego i przestrzennego. Ta niedoskonałość sprawia, iż za turystykę przyjmujemy często zjawiska, które nie spełniają wielu zapisanych $\mathrm{w}$ definicjach warunków. Stąd jeden krok do stwierdzenia, że dane liczbowe o turystyce są mało wiarygodne, gdyż pokazują zafałszowany obraz rzeczywistości. Czy można temu zaradzić? Teoretycznie można, ale praktycznie jest to niemożliwe. Można co prawda przyjąć, że turystą jest osoba, która w danej chwili uważa siebie za turystę, ale takie postawienie sprawy nie daje odpowiedzi na pytanie, czy małe dzieci moga w ogóle być turystami? Ponadto przyjęcie założenia, iż turystą jest tylko ta osoba, która siebie postrzega jako turystę, podważa obowiązujący obecnie system zbierania danych statystycznych o turystyce.

Co więc należy zrobić? Najłatwiej (a może i najlepiej?) jest odpowiedzieć, że nic. Po prostu arrives in Paris on a Sunday in order to see a new exhibition in one of the museums, a tourist (it must be mentioned that he/ she commutes to Paris to work every day)? How in this situation should we understand definitions of tourism which say that during their trips tourists leave their homes? Does 'home' mean the urban agglomeration or just the district where they live? Can a person who for years travels to another city to work every day arrive in the same city during the weekend as a tourist?

Can we call an academic who goes to conferences several times a year (e.g. to Cancun or Las Vegas) a tourist, or a businessman from Australia who has come to Nusa Dua in order to discuss the sale of computer software to one of the hotels?

Is a person who has had health problems for years and come to Bad Homburg for treatment a tourist? After all, care for health is not only a human choice but also a kind of duty imposed by the biological aspect of our existence.

Can we consider a person who has come from Ukraine to Poland and sold a few packets of cigarettes in a border town a tourist? And finally, is a traveller whose life is mostly about travelling and who makes a living from selling photographs and written pieces to magazines a tourist? In both these cases tourism (or perhaps 'tourism'?) is a source of income.

These sorts of questions can be multiplied. They demonstrate the imperfection of common definitions of tourism as a social, economic and spatial phenomenon. Due to this imperfection, we often believe certain phenomena to be tourism, although they do not meet the conditions included in the definitions. This is close to stating that the figures quoted in relation to tourism are unreliable, as they show a false reality. Can something be done about it? Theoretically yes, but practically it is impossible. Although we can assume that a tourist is someone who in a given moment considers him/herself to be one, this assumption does not answer the question at all of whether small children can be tourists. Additionally, the assumption that tourists are only those who perceive themselves as such, questions 
przyjąc za dobrą monetę to co jest. Po co więc te pseudouczone wywody? Po to, abyśmy jako badacze mieli świadomość, iż świat danych, jakimi dysponujemy odnośnie do turystyki, nie jest do końca prawdziwy. Posiadane przez nas dane są wynikiem przyjęcia przez nas pewnej perspektywy badawczej, która może zbliża nas do prawdy, ale nie jest prawdą. Dlatego też nasze wnioski powinny być ostrożne. Wyciagając je musimy cały czas pamiętać, że inni badacze, przy przyjęciu innego podejścia metodologicznego oraz zastosowaniu innych metod badawczych, uzyskaliby prawdopodobnie inny obraz rzeczywistości niż my.

Wydaje się, że zaprezentowane wyżej dylematy zbliżają nas do opowiedzenia się za stosowaniem w badaniach nad turystyką podejścia postmodernistycznego, do którego głównych cech należą m.in. zinstytucjonalizowany pluralizm i heterogeniczność perspektyw badawczych, zwracanie uwagi na sytuacje wyjątkowe (regionalizm), jak również "filozoficzny antyfundamentalizm". Innymi słowy, odrzucenie przyjętych schematów i struktur oraz zgoda na przyjęcie założenia, iż nie ma jedynej i obiektywnej prawdy (http://encyklopedia.pwn. pl/59269_1.html, 26.02.2006).

Głównym celem przyświecającym autorowi tego tekstu jest próba wykazania w nim, iż w geografii turyzmu podejście postmodernistyczne jest nie tylko pewną modą (co dotyczy praktycznie wszystkich nauk spolecznych, w tym również human geography), ale również swojego rodzaju nieuchronnością. Nawet na tle innych dyscyplin geograficznych, a geografia jest przecież dziedziną o słabych podstawach teoretycznych, geografia turyzmu cierpi na brak solidnych, wlasnych podstaw metodologicznych. Jest praktycznie zlepkiem różnych podejść badawczych i nawet neopozytywizm - tak mocny w latach 50.-60. XX w. w human geography - nie mógł się w niej mocniej zakorzenić. Nic więc dziwnego, że w porównaniu $\mathrm{z}$ innymi dyscyplinami human geography w geografii turyzmu doSyć szybko pojawily się prace nawiązujące początkowo do nauk behawioralnych, a potem szybko zbliżające się do podejścia humanistycznego. Stosunkowo w niedlugim czasie pojawiło się w niej również podejście strukturalistyczne. Można przyjąć, że już na przełomie lat 70. i 80. w geografii turyzmu zapanował pluralizm metodologiczny co, w ocenie piszącego te słowa, było w dużej mierze podyktowane słabością podejścia neopozytywistycznego w geografii turyzmu. Dlaczego tak się stało? Przede wszystkim, w porównaniu z innymi dziedzinami human geography, geografia turyzmu the present system of collecting statistical data regarding tourism.

What should be done then? The easiest (and maybe the best) answer is nothing. Perhaps we should accept the situation as it is. So what is the point of these pseudoacademic deliberations? Well, the point is for us as researchers to be aware of the fact that the information that we have about tourism is not completely true. It results from a certain research perspective which perhaps brings us closer to what is true but is not truth. Therefore we should draw our conclusions cautiously. We must keep remembering that other researchers might assume a different methodological approach, use other methods, and arrive at a different picture of reality than us.

It seems that the dilemmas presented above suggest assuming a postmodernist approach in the study of tourism whose main features are institutionalised pluralism and heterogeneity of research perspectives, paying attention to exceptional situations (regionalism), as well as philosophical anti-fundamentalism'. In other words we should reject accepted schemes and structures, and agree to an assumption that there is no single and objective truth (http://encyklopedia.pwn.pl/59269_1. html, 26 February 2006).

The main aim guiding the author is to show that in tourism geography the postmodernist approach is not only fashion (which is true for practically all social sciences, including human geography), but also a kind of necessity. Even when compared to other branches of geography with weak theoretical foundations, tourism geography lacks its own strong methodological base. It is practically a conglomerate of different study approaches and even neo-positivism - so strong in the 1950s and 1960s in human geography could not root into it. It is not surprising then that compared with other branches of human geography, research initially referring to behavioural sciences appeared in tourism geography, and later the humanistic approach. The structural approach also appeared relatively quickly. It can be said that at the turn of the 1980 s tourism geography was marked by methodological pluralism, which in the 
cierpi na niedostatek informacji statystycznych. Wynika to po części z opisanej wyżej specyfiki turystyki i rekreacji (które przez to, że są trudne do zdefiniowania, są również nieuchwytne dla instytucji zajmujących się zbieraniem danych statystycznych), ale w dużym stopniu jest również spowodowane położeniem przez organy statystyczne (niemal na całym świecie) znacznie większego nacisku na zbieranie informacji dotyczących demografii, rolnictwa, produkcji przemysłowej, transportu, poziomu życia lub handlu. Ponadto, z racji swojej słabości w sferze podstaw teoretycznych, geografia turyzmu ma bardzo ścisłe związki z innymi naukami społecznymi zajmującymi się turystyką i rekreacją. Ponieważ w socjologii, psychologii, ekonomii czy antropologii kulturowej podejścia alternatywne wobec neopozytywistycznego modelu nauki pojawily się szybciej niż w geografii, z racji istniejących już wcześniej powiązań, w relatywnie krótkim czasie nowe tendencje dotarły również do geografii turyzmu.

\section{DYLEMAT PIERWSZY - NIEJEDNO- ZNACZNOŚĆ POJECIA „TURYSTYKA”}

Socjolog K. Przecławski definiuje turystykę jako zjawisko spoleczne obejmujące wszystkie zjawiska ruchliwości przestrzennej związane $\mathrm{z}$ dobrowolna, czasową zmianą miejsca pobytu, rytmem i środowiskiem życia oraz z wejściem w styczność osobistą ze środowiskiem odwiedzanym (przyrodniczym, kulturowym bądź społecznym - PRZECŁAWSKI 1994, 9). Inaczej widzi turystykę DĘBSKI (1974), który uważa, że turystyka zawiera ogół stosunków spolecznych i zjawisk gospodarczych, obejmujących swym zasięgiem proces wytwarzania usług $\mathrm{i}$ ich konsumpcji przez osoby okresowo przebywające poza miejscem stałego zamieszkania w celach co najmniej pośrednio związanych z krajoznawstwem i rekreacja. Ten sam autor zwraca uwagę na fakt, iż $z$ definicji pojęcia „turystyka” wynika, że zawiera ona zarówno sferę konsumpcji rozmaitych dóbr i uslug w czasie przejazdu i przebywania w miejscu okresowego zatrzymania i sferę wytwarzania dóbr i usług oraz obrót nimi.

Z kolei LISZEWSKI (1995, s. 94) definiuje turystykę (jak podaje autor, w znaczeniu largo) jako zjawisko przestrzenne, społeczno-kulturowe i ekonomiczne, polegające na dobrowolnej, czasowej zmianie miejsca stałego pobytu człowieka w celach wypoczynkowych, poznawczych oraz doznania przeżyć intelektualnych i emocjonalnych. author's opinion, resulted from weakness in the neo-positivist approach. Why did it happen? First of all, in contrast with other branches of human geography, tourism geography lacks statistical data. This is partly caused by the special character of tourism and recreation described above (they are difficult to define and, consequently, difficult for statistical institutions to monitor), as well as by the fact that worldwide statistical data focuses on demography, agriculture, industry, transport, standard of living, or commerce. Besides, tourism geography, due to its weak methodological foundations, relies heavily on other social sciences dealing with tourism and recreation. Because in sociology, psychology, economics and cultural anthropology, alternatives to the neopositivist model of science appeared earlier than in geography, the new trends reached tourism geography relatively soon.

\section{DILEMMA ONE - THE AMBIGUITY OF THE TERM 'TOURISM'}

Przecławski, a sociologist, defines tourism as a social phenomenon including all spatial mobility involving a voluntary, temporary change of residence, rhythm and environment, as well as personal contact with the visited environment (natural, cultural and social) - (PRZECEAWSKI 1994, 9). Tourism is perceived differently by DEBBSKI (1974) who believes that it comprises all social relations and economic phenomena which involve the processes of service production and consumption by those temporarily away from home for purposes at least partly related to tourism and recreation. The same author points to the fact that the definition of 'tourism' suggests that it includes both the sphere of goods and service consumption at the time of travel, and the sphere of their production and sale.

LISZEWSKI (1995, 94) defines tourism (sensu largo) as a spatial, socio-cultural and economic phenomenon, of a voluntary, temporary change of residence for recreational or educational purposes, and for intellectual and emotional experience. 
Podobnie traktują turystykę inni autorzy - np. GUNN (1988) przyjmuje za turystykę wszystkie podróże, poza dojazdami do pracy. Jednak cytowany pogląd spotkal się z silnym sprzeciwem m.in. SHAW I WILLIAMSA $(1996,5)$, których zdaniem powyższa definicja jest zbyt szeroka i nieprecyzyjna. Z kolei wloski socjolog CosTA $(1987,353)$ umieszcza turystykę między „wypoczywaniem” a „koczowaniem”, wyróżniając równocześnie „podróżowanie”, które zawiera w sobie zarówno elementy wypoczynku, jak i koczowania. Opinia N. Costy nawiązuje do koncepcji COHENA (1973), który wprowadza dla różnych typów turystów pojęcia vacationer, sightseer i drifter. To ostatnie pojęcie było także używane przez OPPERMANNA $(1993,541)$, ale w celu określenia turystów dysponujących małymi środkami finansowymi i uprawiającymi tzw. drifter tourism (inaczej low budget tourism).

To co wyżej napisano sprawia, iż już przy ustaleniu zakresu terminu ,turystyka" są duże kłopoty z przyjęciem jednej definicji. Należy ponadto nadmienić, że w ostatnich latach, wraz z pojawieniem się nowych form turystyki, problem ten nie tylko nie został rozwiązany, ale wydaje się, iż upragnione rozwiązanie zaczęło się oddalać. Oto dowody.

W ostatnich latach pojawily się nowe określenia rodzajów turystyki, które wcześniej bądź praktycznie nie występowały, bądź z powodu swojej incydentalności byly zaliczane do bardziej ogólnych form turystyki. Takimi nowymi pojęciami są terminy w rodzaju research tourism (używana jest również nazwa scientific tourism), archeological tourism, ethno-tourism (czasami nazywana tribal tourism), esoteric tourism czy nawet astronomical tourism. (Te dwa ostatnie określenia występują np. na stronie internetowej gminy $\mathrm{La}$ Serena w środkowej części Chile (http://www. laserena/page_eng/razones_invertir_tur_eng.php, 23.02.2006).

Wiele $\mathrm{z}$ tych form jest zaliczanych do tzw. turystyki niszowej (niche tourism). Wspólną ich cechą jest ich poznawczy charakter, a w niektórych $\mathrm{z}$ nich trudno dopatrzyć się elementów rekreacji, typowej dla tzw. turystyki masowej. Są one raczej wyrazem pewnych postaw, niż chęci odpoczynku. Ponieważ tego typu wyjazdy są na ogół organizowane - czasami jest to wynik przyjętej przez turystów ideologii - z pominięciem biur podróży, hoteli itp., są one trudne do zidentyfikowania przez instytucje zajmujące się rejestracją ruchu turystycznego.
Tourism is treated in a similar way by other authors - e.g. GUNN (1988) sees all travel, except commuting to work, as tourism. However, this opinion was strongly contradicted by SHAW \& WILLIAMS $(1996,5)$ who claim this is too wide and lacks precision. An Italian sociologist COSTA $(1987,353)$ places tourism between 'resting' and 'wandering', separating out 'travelling' at the same time which combines elements of both. Costa's position links to that of Cohen who introduced the terms vacationer, sightseer and drifter for different types of tourists. The last term was also used by OPPERMANN $(1993,541)$, but to define tourists with small financial means as drifter tourism or low budget tourism.

It is very difficult to formulate a single definition of tourism. In recent years new forms of tourism have appeared and the problem not only has not been solved but it seems that a solution has become even harder to find. Here is some evidence.

Recent years have brought new terms for types of tourism which had not occurred before or so rarely that they were included in more general forms. Among these new terms we find research tourism (or scientific tourism), archaeological tourism, ethnotourism (or tribal tourism), esoteric tourism, or even astronomical tourism (the last two can be found on the website of La Serena in central Chile: www.laserena/page_eng/ razones_invertir_tur_eng.php, 23 February 2006).

Many of these are subsumed under niche tourism. They are all educational and in some it is difficult to find the elements of recreation typical of popular tourism. They express certain attitudes rather than a willingness to rest. As this sort of trip is usually organized without travel agencies, hotels, etc. (sometimes it is a tourists' conscious choice based on the ideology they believe in), they are difficult to identify by institutions collecting records of tourist activity.

One form of tourism which has probably occurred before, but started to be defined by a separate term only recently, is esoteric tourism. It can be described as an interest in places which lend themselves to medita- 
Jedną z form turystyki, która najprawdopodobniej występowała już wcześniej, ale dopiero calkiem niedawno zaczęla być określana odrębnym zwrotem, jest esoteric tourism. Turystykę ezoteryczną można zdefiniować jako zainteresowanie miejscami związanymi z oddawaniem się praktykom sprzyjającym medytacji i odnowie duchowej. Według osób uprawiających tę formę turystyki takimi miejscami są megality (np. znajdujące się w Bretanii czy Stonehenge w Wielkiej Brytanii), świątynie cywilizacji pozaeuropejskich (głównie Majów, Inków i Azteków), ruiny dawnych „miast” (np. Nan Madol na wyspie Pohnpei w Mikronezji) itd., jak również społeczności, w których kulturze dużą rolę odgrywa magia (np. Tybetańczycy, wyznawcy kultu voodoo na Haiti). Wzrost zainteresowania wyjazdami do regionów otoczonych nibem tajemniczości, zwiedzanie miejsc związanych z magią i specjalnym kultem, oddawanie się medytacjom i uczestniczenie w różnorodnych obrzędach należy przede wszystkim wiązać z ideologią new age, którą przyjęlo się uważać za jeden z czołowych przejawów postmodernizmu w kulturze. (Chociaż esoteric tourism jest uprawiana glównie przez mieszkańców Europy i Ameryki Północnej, to do miejsc chętnie przez nich odwiedzanych należy w dużej mierze Ameryka Południowa - Peru, Chile, Brazylia, a celem wyjazdów są często miejsca kultu Inków oraz współczesnych Indian).

Wszystko to co dotąd napisano składa się na dosyć ponury obraz jeżeli chodzi o zbliżenie się do przyjęcia w miarę jednoznacznej definicji turystki. Należy przyjać, że nawet gdy zgodzimy się na jakąś definicję, która będzie mogła być zalecana przez World Tourism Organization, to jednak pozostaną liczne formy turystyki, które nie zmieszczą się w przyjętej definicji, a tym samym „wymkną" się instytucjom zobowiązanym do zbierania danych statystycznych o turystyce. Tak więc nadal wiele zachowań stricte turystycznych będzie „,niewidocznych".

Kolejnym problemem związanym $\mathrm{z}$ terminologią turystyczną jest brak zgody co do znaczenia poszczególnych terminów. (Co prawda MEDLIK (1995) opracował słownik pojęć turystycznych, ale jest on bardziej przydatny dla praktyków, niż dla teoretyków. Podobnie można traktować zalecenia World Tourism Organization.). Przykładem sporów na temat roli poszczególnych pojęć może być ciaggly dylemat, jak odróżnić tourists od visitors, tourism od recreation, tourist infrastructure od tourist services itp. W tym ostatnim przypadku jest jeszcze jeden problem. Gdzie przebiega rozgrani- tion and spiritual renewal. According to those involved this includes megaliths (e.g. in Brittany, or Stonehenge in Great Britain), temples of non-European civilizations (mainly the Mayas, Incas and Aztecs), ruins of ancient cities (e.g. Nan Madol on the Pohnpei island in Micronesia), etc. Esoteric tourism also includes communities in whose cultures magic plays an important role (e.g. the Tibetans or voodoo worshippers in Haiti). The growing interest in journeys to mysterious regions, visits to places connected with magic and special cults, meditation and taking part in a variety of rituals, are all related to new age ideology which is regarded as one of the main manifestations of postmodernism in culture. Although esoteric tourism is popular mainly with the inhabitants of Europe and North America, the places which they are willing to visit are largely found in South America - Peru, Chile, Brazil, and the sites of Inca cult or those of contemporary South American Indians are frequently chosen destinations.

All that has been discussed so far does not promise well for a universal definition of tourism. It should be assumed that even if we accept the definition recommended by the World Tourism Organization, there will still remain many forms of tourism not covered by it, and which will 'escape' the institutions responsible for collecting tourism statistical data. Many kinds of true tourist behaviour will still be 'invisible'.

Another problem concerning tourism terminology is a lack of agreement as to the meaning of individual terms. MEDLIK (1995) has prepared a dictionary of tourism terms but it seems of more use to practitioners rather than to theoreticians. The same concerns the World Tourism Organization's recommendations. An example of disagreement here can be the continual dilemma of how to differentiate between tourists and visitors, tourism and recreation, tourist infrastructure and tourist services, etc. In the case of the last example there is yet a further problem. What is the difference between tourist infrastructure and tourist resources? Is a museum a cultural resource or an element of auxiliary infrastructure? It can of course be assumed 
czenie między tourist infrastructure a tourist resources? Czy muzeum jest zasobem kulturowym czy też elementem infrastruktury towarzyszącej? Można oczywiście przyjać, że zależy to od tego, czy jego odwiedzenie jest głównym celem przyjazdu turysty (wtedy muzeum jest walorem) czy też turysta - który przybyl do danej miejscowości, po to aby się opalać na plaży - udaje się do niego w czasie niepogody (wówczas muzeum jest jednym $\mathrm{z}$ elementów infrastruktury). Ale takie rozróżnienie można zrobić dopiero po stwierdzeniu motywów przyjazdu turysty, co wymaga przeprowadzenia odrębnych badań.

Przykładem zamętu pojęciowego jest rozróżnianie w polskim nazewnictwie turystycznym pojęć valeur i resource. Uważa się, że resources występują obiektywnie, a valeur są wynikiem oceny resource pod kątem turystyki (KOWALCZYK 2000). Jednak można na tę sprawę spojrzeć inaczej i przyjąć, że określenie valeur zostało zapożyczone z języka francuskiego, a resource $\mathrm{z}$ języka angielskiego, gdyż jedni badacze byli obeznani głównie z literaturą anglojęzyczna, a inni studiowali we Francji lub czytali literaturę w języku francuskim.

Również pojęcie chłonności jest różnie rozumiane. Ponieważ tego rodzaju przykłady można mnożyć, na zakończenie autor prezentowanego tekstu chce jedynie zwrócić uwagę na ewolucję znaczenia niektórych pojęć.

Jak już wcześniej podano, jedną z cech podejścia postmodernistycznego w nauce jest nieprzywiązywanie nadmiernej wagi do znaczenia używanych terminów. W naukach o turyzmie, nie wyłączając geografii turyzmu, jest tak np. z określeniem ecotourism, które jest jeszcze często traktowane jako synonim nature tourism (takie podejście można było szczególnie często spotkać na przełomie lat 80. i 90.), ale coraz więcej badaczy rozumie je w sposób bliski określeniu sustainable tourism. Innym przykładem zmian w rozumieniu danego pojęcia może być ewolucja poglądów co do znaczenia zwrotu alternative tourism. Jeszcze na początku lat 90 . było ono $z$ reguły używane zamiennie $\mathrm{z}$ pojęciem ecotourism, a słowo „alternative" było rozumiane jako przeciwstawienie określeniom "popular", czy „mass" (mass tourism). Jednak od kilku lat alternative tourism jest również używane jako termin opisujący turystykę uprawianą przez osoby o orientacji homoseksualnej, która bywa również określana terminami gay tourism, gay \& lesbian tourism, pink tourism, queer tourism oraz homosexual tourism. ${ }^{1}$ Ta wielość określeń tej samej formy turystyki wcale nie that it depends on whether a visit to the museum is the tourist's main aim (then the museum is a resource), or whether the tourist, who arrived in a given destination in order to sunbathe on the beach, goes to the museum when the weather is bad (then the museum is a part of the infrastructure). Such a differentiation, however, can be made only after the motives of the tourist's visit are confirmed, which requires separate research.

An example of the chaos in Polish tourist terminology is the differentiation between valeur and resource. It is believed that resources occur objectively and a valeur is a result of an evaluation of the resource from the tourist's point of view (KowALCZYK 2000). This matter, however, can be approached differently and we can assume that the term valeur has been borrowed from French, and the term resource from English, because some researchers were familiar mainly with the English literature, and others studied in France or read the French literature in original.

Also the term capacity is understood in different ways. Because of the great number of such examples, the author wishes only to draw attention to the evolution of the meaning of some terms.

As said before, one of the characteristic aspects of the postmodernist approach is not attaching excessive importance to the meaning of the terms in use. In tourism studies, including tourism geography, this is the case with ecotourism, which is often treated as a synonym of nature tourism (popular at the turn of the 1990s), but currently often understood in the sense of sustainable tourism. Another example of a change in understanding of a given term is the evolution of the expression alternative tourism. In the early 1990s it was usually used interchangeably with ecotourism, and the word 'alternative' was seen as opposed to 'popular' or 'mass' (mass tourism). However, for a number of years the term alternative tourism has also been used as a term describing homosexual tourism. This is also referred to as gay tourism, gay \& lesbian tourism, pink tourism, queer tourism and homosexual tourism. ${ }^{1}$ This variety of terms 
zbliża do rozwiązania problemów z przyjęciem jednoznacznego rozumienia poszczególnych pojęć. ${ }^{2}$

\section{DYLEMAT DRUGI - KEOPOTY $Z$ OKREŚLENIEM ZAKRESU GEOGRAFII TURYZMU}

Podobnie jak i w innych dyscyplinach geografii, geografia turyzmu doczekała się licznych definicji. Chociaż ich przytaczanie nie wydaje się być celowe, to jednak warto zwrócić uwagę na kilka kwestii.

W literaturze przedmiotu występują obok siebie określenia tourism geography (chyba najczęściej stosowane), travel geography, tourist geography, geography of tourism i kilka innych (w rodzaju leisure geography, recreation geography itp.). Często określenia te są traktowane zamiennie, aczkolwiek wydaje się, że czym innym jest szeroko definiowana tourism geography, a czym innym wąsko pojmowana tourist geography (touristic geography), która jest rozumiana jako distribution of tourists in the different regions.

W latach 90. pojawily się również poglądy, iż geografię turyzmu, przy założeniu, że jest ona ciągle częścią human geography, można właściwie podzielić na dwa nurty: kierunek nazywany economic tourism geography (lub economic geography of tourism industry, jak stosuja D. Ioannides i K. G. Debbage) oraz cultural tourism geography. Wydaje się, że głoszenie takich poglądów - które wcale nie są tak abstrakcyjne, gdyż w dużej mierze odpowiadają faktom - znacznie osłabia pozycję geografii turyzmu jako subdyscypliny geografii, jak również samej geografii jako dziedziny zajmującej się przestrzennymi aspektami turystyki. Można przyjąć, że zasygnalizowana economic tourism geography w rzeczywistości stanie się bardzo bliska ekonomii turystyki, natomiast cultural tourism geography będzie trudna do odróżnienia od antropologii turystyki.

W tym miejscu przechodzimy do kolejnego problemu, a mianowicie określenia miejsca geografii turyzmu wśród innych dyscyplin badających turystykę. Tradycyjnie dyscyplinami, które zajmowały się turystyką i rekreacją na równi z geografią były ekonomia, socjologia i antropologia kulturowa oraz psychologia i pedagogika. Ostatnio poważnymi konkurentami dla geografii turyzmu stały się geologia oraz nauki rolnicze. W przypadku tej pierwszej dyscypliny chodzi o tzw. used for the same form of tourism does not bring us closer to a clear understanding of individual expressions. ${ }^{2}$

\section{DILEMMA TWO - PROBLEMS DEFINING THE SCOPE OF TOURISM GEOGRAPHY}

Like other branches of geography, tourism geography has been defined in many ways. Although quoting them does not seem necessary, some aspects are worth pointing to.

In the literature we find the following terms: tourism geography (perhaps the most popular), travel geography, tourist geography, geography of tourism and several others such as leisure geography, recreation geography, etc. These are frequently used interchangeably, although it seems that the wide scope of tourism geography differs from the narrow scope tourist geography (touristic geography), which is understood as the distribution of tourists in different regions. The 1990s brought suggestions that tourism geography, assuming that it is still part of human geography, can be divided into economic tourism geography (or economic geography of the tourism industry), a term used by Ioannides \& Debbage, and cultural tourism geography. It seems that expressing such positions, which are not at all abstract because they reflect facts, considerably weakens the position of tourism geography as a branch of geography, as well as of geography itself as an academic subject dealing with the spatial aspects of tourism. It can be assumed that economic tourism geography will in fact become very close to tourism economics, while cultural tourism geography will be difficult to distinguish from the anthropology of tourism.

At this point the next issue, the place of tourism geography among other tourismrelated disciplines, will be introduced. Traditionally, the disciplines which dealt with tourism and recreation, along with geography, were economics, sociology, cultural anthropology, psychology and pedagogy. Recently, geology and agri-culture have become serious competitors to tourism 
geotourism, natomiast dyscypliny rolnicze wykazują coraz większe zainteresowanie nie tylko agrotourism, ale również ecotourism (w znaczeniu nature tourism), cultural tourism oraz sport tourism. Pojawienie się zainteresowania tych dwóch dyscyplin turystyką jest o tyle ważne, że wcześniej domeną geografii w badaniach nad turystyką i rekreacją było zajmowanie się ich uwarunkowaniami i następstwami przyrodniczymi oraz ujęcie przestrzenne. W przypadku zainteresowania turystyką ze strony geologii, ten pierwszy argument staje się częściowo nieaktualny. Również z powodu dosyć silnych powiązań nauk rolniczych $\mathrm{z}$ przyrodą i przestrzenią (co prawda wiejska), założenie, że przede wszystkim geografia ma prawo do zajmowania się przyrodniczymi aspektami turystyki, staje się anachroniczne.

\section{PODSUMOWANIE}

Z tego co wyżej napisano wynika, że obraz zakresu geografii turyzmu - podobnie jak i turystyki jako takiej - jest raczej rozmyty (fuzzy), co sprawia, iż trudno ustalić jej definicję, przyjąć katalog precyzyjnie zdefiniowanych pojęć, jak również zgodzić się na stosowanie ściśle określonych podejść i metod badawczych. Wydaje się raczej, iż geografia turyzmu jest swojego rodzaju zbiorem mozaik, które można nazwać jako mozaikę:

- poglądów odnośnie do istoty turystyki,

- pojęć związanych z turystyka,

- danych dotyczących turystyki,

- definicji geografii turyzmu,

- koncepcji badawczych stosowanych w geografii turyzmu,

- metod badawczych używanych w geografii turyzmu.

Ta „mozaikowość” geografii turyzmu sprawia, że nigdy nie występował w niej nadmierny rygoryzm metodologiczny tak typowy dla neopozytywizmu. W ostatnich latach trend ten umocnił się, czemu sprzyjają nowe zjawiska zachodzące w światowej turystyce, jak również czego dowodem mogą być najnowsze publikacje dotyczące turystyki, W których układzie treści można spotkać pomieSzanie podejścia przedmiotowego (szukanie odpoWiedzi na pytanie „,co?”, np. „co uprawiaja turyści?”) z podejściem podmiotowym („,kto?”). DoWodem na występowanie tych tendencji (dowody te chyba w pelni potwierdzają istnienie zjawiska „postmodernizmu” we współczesnej turystyce) geography. In the case of the former we talk about geotourism, while the latter shows a growing interest not only in agro-tourism, but also in ecotourism (in the sense of nature tourism), cultural tourism and sport tourism. The fact that these two disciplines have become interested in tourism is important; prior to that the involvement of geography in tourism and recreation was limited to the study of natural conditions and the consequences to the natural environment, as well as the spatial approach. If we consider geology, the first argument becomes irrelevant. Also, because of the strong links between the discipline of agriculture and nature and space (rural), the assumption that it is mainly geography that should deal with the natural aspects of tourism seems outdated.

\section{CONCLUSIONS}

It can be concluded that the range of tourism geography, as well as of tourism itself, is rather fuzzy, which makes it difficult to formulate its definition, establish a catalogue of precise terms or agree to apply strictly defined approaches and research methods. It seems that tourism geography is a particular mosaic of the following:

- opinions concerning the essence of tourism,

- tourism-related terms,

- tourism-related data,

- definitions of tourism geography,

- academic concepts applied in tourism geography,

- research methods used in tourism geography.

This mosaic character of tourism geography has always eliminated the excessive methodological rigour so typical of neopositivism. In recent years this trend has become stronger due to new phenomena in global tourism. They have been described in the most recent publications on tourism where we can find a mixture of an objective approach (looking for answers to questions such as 'what do tourists do?') and a subjective approach ('who?'). This tendency is demonstrated by two examples 
mogą być dwa przykłady. Pierwszy związany jest z Las Vegas, w którym powstały hotele przypominające pod względem architektonicznym Wenecję, Nowy Jork czy budowle wzniesione w starożytnym Egipcie. Drugi dotyczy leżącego w pobliżu zachodniego krańca jeziora Balaton (Węgry) rejonu uzdrowiska Hévíz, gdzie jedną z głównych atrakcji turystycznych jest zbudowana w $1992 \mathrm{r}$. buddyjska stupa (największa w Europie), wzniesiona na zalesionym wzgórzu nad miejscowością Zalaszántó.

$\mathrm{Z}$ kolei świadectwem upowszechniania się podejścia posmodernistycznego $\mathrm{w}$ sferze badawczej może być wydana w 2005 r. książka pod red. M. Novelli, w której obok rozdziałów poświęconych sport tourism czy adventure tourism (co?), jest rozdzial youth tourism (kto?), a także rozdziały voluntary tourism (jak?) oraz virtual tourism (gdzie?). Czy to nie jest postmodernizm?

Kończąc artykuł, autor pragnie na chwilę powrócić do jego tytułu. Wydaje się, że podejście postmodernistyczne $\mathrm{w}$ geografii turyzmu, które niewątpliwie wiąże się $\mathrm{z}$ pewną modą występująca w naukach społecznych, jest jednak dla niej również nieuchronnością.

\section{PRZYPISY}

\footnotetext{
${ }^{1} \mathrm{~W}$ wyszukiwarce internetowej google.com (23.02.2006) haslo gay tourism dało 57100 wyników, gay \& lesbian tourism 6330, pink tourism 1240, homosexual tourism 845, a queer tourism 656. Mimo tak znacznych różnic, wszystkie nazwy sq̨ w użyciu, a queer tourism występuje nawet w tytule jednej z książek.

${ }^{2}$ Problem ten dotyczy również często używanego ostatnio terminu ,new" tourism. Dla jednych są to nowe formy turystyki, a dla innych nowe sposoby świadczenia usług turystycznych.
}

(and they fully confirm the occurrence of 'postmodernism' in contemporary tourism): the first is Las Vegas with its hotels built in Venetian, New York or ancient Egyptian styles; the other is the Heviz health resort not far from the western end of Lake Balaton (Hungary) where one of the main tourist attractions is the Buddhist stupa, built in 1992 (the largest in Europe) on a forested hill in Zalaszántó.

The popularity of the postmodernist approach in research can be observed in the book edited by Novelu (2005), where next to chapters devoted to sport tourism or adventure tourism ('what?') there is also a chapter devoted to youth tourism ('who?'), as well as others referring to voluntary tourism ('how?') and virtual tourism ('where?'). Isn't that postmodernism?

To conclude the author would like to refer back to the title of the article. It appears that the postmodernist approach in tourism geography, which is certainly connected with fashion in social sciences, is also inevitable.

\section{NOTES}

1 Google.com (23.02.2006) provided 57,100 references to gay tourism, 6330 to gay \& lesbian tourism, 1240 to pink tourism, 845 to homosexual tourism and 656 to queer tourism. Despite such differences, all the terms are in use and queer tourism appears even in the title of a book.

2 The problem also concerns the term 'new' tourism, recently frequently used. For some they are new forms of tourism, for others - new ways of providing tourist services.

\section{BIBLIOGRAFIA - BIBLIOGRAPHY}

COHEN E., 1973, Nomads from affnence: notes on the phenomenon of drifter-tourism, International Journal of Comparative Sociology, 14, 1/2, s. 89-103.

Costa N., 1987, Il turista come vinggiatore, Politica del Turismo, IV, 3 (luglio-settembre), s. 351-363.

DEBSKI L. A., 1974, Programowanie i lokalizacja urzadzeń turystycznych, Instytut Turystyki, Warszawa.

GunN C. A., 1988, Tourism planning, Taylor \& Francis, New York.

http://encyklopedia.pwn.pl/59269_1.html (26.02.2006).

http://www.laserena/page_eng/razones_invertir_tur_eng. php (23.02.2006).

IOANNIDES D., DEBBAGE K. G. (red.), 1998, The economic geography of the tourist industry. A supply-side analysis, Routledge, London-New York.

KowalczYK A., 2000, Geografia turyzmu, PWN, Warszawa. Liszewski S., 1995. Przestrzeń turystyczna, Turyzm. 5/2, s. $87-103$.
MEDLIK S., 1995, Leksykon podróźy, turystyki i hotelar stwa. PWN, Warszawa.

MidDLETON V. T. C., 1996, Marketing $w$ turystyce, PAPT, Warszawa.

Noveldi M., 2005, Niche tourism. Contemporary issues, trends and cases, Elservier - Butterworth Heinemann, Oxford.

OPPERMANN M.. 1993, Tourism space in developing countries, Annals of Tourism Research, 20, 3, s. 535556.

PRZECLAWSKI K., 1994, Turystyka a świat wspótczesny, Uniwersytet Warszawski, Warszawa.

Shaw G., Williams A. M., 1996, Critical issues in tourism A geographical perspective, Blackwell Publishers Inc. Oxford-Cambridge, MA.

ŚWIECICKA K., 1993, Husserl, ser. „Myśli i ludzie”, Wiedza Powszechna, Warszawa. 